\title{
Development of Plants from Single- node Cuttings Differs among Cultivars of Red Maple and Freeman Maple
}

\author{
Lorna C. Wilkins \\ Department of Horticulture, University of Maryland, College Park, \\ MD 20742-5611 \\ William R. Graves ${ }^{1}$ \\ Department of Horticulture, Iowa State University, Ames, IA 50011-1100
}

\begin{abstract}
Alden M. Townsend
U.S. Department of Agriculture, Agricultural Research Service, National Arboretum, Washington, DC 20002

Additional index words. Acer rubrum, Acer $\times$ freemanii, woody landscape plants, propagation
\end{abstract}

Abstract. Six red maple (Acer rubrum L.) and four Freeman maple (A. xfreemanii E. Murray) cultivars were compared for rooting of single-node stem cuttings and subsequent development of rooted cuttings. Cuttings were taken in May 1990 and 1991 and treated with either 3 or $8 \mathrm{~g} \mathrm{IBA} / \mathrm{kg}$. Rooting after 4 weeks differed among cultivars, ranging from $22 \%$ for 'Karpick' to $100 \%$ for 'Schlesinger' over both years. Rooting scores, based on root counts and lengths, were highest for 'Schlesinger' and lowest for 'Scarlet Sentinel' and 'Karpick'. IBA at $8 \mathrm{~g} \cdot \mathrm{kg}^{-1}$ resulted in better rooting than at $3 \mathrm{~g} \cdot \mathrm{kg}^{-1}$. Mean length of shoots formed on potted rooted cuttings was $22.6 \mathrm{~cm}$ for 'Franksred', which initiated shoots on $100 \%$ of the cuttings that rooted. In contrast, $<50 \%$ of 'Armstrong', 'Jeffersred', 'Karpick', 'Northwood', and 'Scarlet Sentinel' rooted cuttings initiated shoots, and mean length of new shoots was $<4 \mathrm{~cm}$ for these cultivars. The amount of leaf desiccation that occurred after removing cuttings from the propagation bench varied among cultivars, and the percentage of viable leaf surface area correlated positively with final root or shoot dry mass for all cultivars. Chemical name used: indole-3-butyric acid (IBA).

Red maple and Freeman maple cultivars are propagated from softwood cuttings because $>50 \%$ of budded and grafted plants can fail after 1 year (Fare et al., 1990; Moller, 1985). Dirr and Heuser (1987) recommended using softwood cuttings $\leq 23 \mathrm{~cm}$ long with two to four nodes. Using shorter, single-node cuttings could increase the number of propagules from a stock block and reduce the space required for handling (English, 1981; Orton, 1978). Although success with single-node cuttings has been reported for 'Franksred' (trademark, Red Sunset) and 'October Glory' (Orton, 1978; Smalley and Dirr, 1987a, 1987b), information on other cultivars is needed because of genetic differences (Bachtell, 1989; Townsend, 1977) among them. Our objective was to compare six cultivars of red maple and four cultivars of Freeman maple for root and shoot development on single-node cuttings.

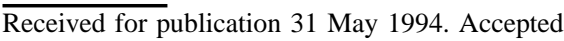
for publication 27 Nov. 1994. Scientific article A6604, contribution 8818 from the Maryland Agricultural Expt. Station. We thank J. Frank Schmidt \& Son, Boring, Ore., for supplying plant material. The cost of publishing this paper was defrayed in part by the payment of page charges. Under postal regulations, this paper therefore must be hereby marked advertisement solely to indicate this fact.

${ }^{1}$ To whom reprint requests should be addressed.
}

\section{Materials and Methods}

Dormant, 2-year-old 'Autumn Flame', 'Franksred', 'Karpick', 'Northwood', 'October Glory', and 'Schlesinger' red maple and 'Armstrong', 'Indian Summer', 'Jeffersred' (trademark, Autumn Blaze), and 'Scarlet Sentinel' Freeman maple (Dirr, 1990) plants were obtained from J. Frank Schmidt \& Son Co., Boring, Ore. The plant liners, produced from stem cuttings, were planted in containers from 7 to 9 Mar. 1990 and grown in a glasshouse. The same plants were returned to the glasshouse from 20 to 25 Mar. 1991 after storage for 3 months at $\approx 4 C$. Single-node cuttings with two leaves were taken on 22 and 23 May 1990 and 1991 from the fourth through seventh youngest nodes of growing stems. Stem sections were $5 \mathrm{~cm}$ long and $\approx 0.5 \mathrm{~cm}$ in diameter, with cuts made $1 \mathrm{~cm}$ above and $4 \mathrm{~cm}$ below the node (Orton, 1978; Smalley and Dirr, 1987a, $1987 b)$. Stems were scraped with a razor blade to remove the epidermis on two sides of the basipetal $1.5 \mathrm{~cm}$. The wounded region was coated with talc containing 3 or $8 \mathrm{~g} \mathrm{IBA} / \mathrm{kg}$ (Hormodin no. 2 or 3; MSD-AGVET, Rahway, N.J.). In 1990 and 1991, there were 18 cuttings in both IBA treatments for each cultivar, except 'Karpick', which was used only in 1991 when 18 and 36 cuttings were treated with 3 and $8 \mathrm{~g} \mathrm{IBA} / \mathrm{kg}$, respectively. All cuttings were inserted in coarse perlite in 801 flats
(Landmark Plastic Corp., Akron, Ohio), with three cuttings per cell of the flats in a completely randomized design. Flats were placed on a glasshouse bench and misted with tap water for 6 to $8 \mathrm{sec}$ every $4 \mathrm{~min}$. Mist was reduced successively to $12 \mathrm{sec}$ every $8 \mathrm{~min}$ on 6 June, 8 sec every 16 min on 12 June, and 12 sec every $32 \mathrm{~min}$ on 17 or 18 June in both years. Daily maximum/minimum air temperature adjacent to the cuttings on the mist bench averaged 28/19C and 34/23C in 1990 and 1991, respectively. Maximum photosynthetically active radiation (PAR) during the two experiments was $1100 \mu \mathrm{mol} \cdot \mathrm{m}^{-2} \cdot \mathrm{s}^{-1}$. No bottom heat or supplemental irradiation was used.

Cuttings were removed from perlite after 4 weeks (19 and 20 June), and rooting was scored based on the number and length of roots (Table 1). Scoring criteria served as a rapid, nondestructive estimation of rooting based on root development in this study, but these criteria may not be suitable for other experiments. In 1991, rooted cuttings were potted singly in 2 peat : 2 perlite : 1 Earth Life (Metcalf \& Eddy, Baltimore) (by volume) in 2-liter plastic nursery containers (Zarn, Reidsville, N.C.) $(16 \mathrm{~cm}$ in diameter) and irrigated with tap

Table 1. Scoring categories used to describe differences in root development on single-node cuttings.

\begin{tabular}{lcc}
\hline Score & $\begin{array}{c}\text { Roots } \\
(\text { no. })\end{array}$ & $\begin{array}{c}\text { Longest roots } \\
(\mathrm{cm})\end{array}$ \\
\hline 0 & 0 & 0 \\
1 & $<4$ & $<2.5$ \\
2 & $4-10$ & $<5$ \\
3 & $>10$ & Two or three roots $>5$ \\
4 & $>10$ & More than three roots $>5$ \\
5 & $>10$ & Two or more roots $>8$ \\
\hline
\end{tabular}

Table 2. Percent rooting and mean root score of single-node cuttings of red maple and Freeman maple cultivars in 1990 and 1991 using 3 or $8 \mathrm{~g}$ IBA $/ \mathrm{kg}$.

\begin{tabular}{|c|c|c|}
\hline Variable & $\begin{array}{l}\text { Cuttings that } \\
\text { rooted } \\
(\%)^{\mathrm{z}}\end{array}$ & $\begin{array}{c}\text { Mean } \\
\text { root scorey }\end{array}$ \\
\hline \multicolumn{3}{|l|}{ Red maple } \\
\hline Autumn Flame & 92 & 3.1 \\
\hline Franksred & 96 & 3.7 \\
\hline Karpick & 22 & 0.2 \\
\hline Northwood & 86 & 2.2 \\
\hline October Glory & 92 & 2.8 \\
\hline Schlesinger & 100 & 4.1 \\
\hline \multicolumn{3}{|l|}{ Freeman maple } \\
\hline Armstrong & 73 & 1.8 \\
\hline Indian Summer & 85 & 2.4 \\
\hline Jeffersred & 90 & 2.1 \\
\hline Scarlet Sentinel & 47 & 0.8 \\
\hline $\operatorname{LSD}_{0.05}$ & 31 & 0.9 \\
\hline \multicolumn{3}{|l|}{$\operatorname{IBA}\left(\mathrm{g} \cdot \mathrm{kg}^{-1}\right)$} \\
\hline \multicolumn{3}{|l|}{1990 (all cultivars) } \\
\hline 3 & 67 & 1.6 \\
\hline 8 & 88 & 2.6 \\
\hline $\mathrm{LSD}_{0.05}$ & 20 & 0.2 \\
\hline \multicolumn{3}{|l|}{1991 (all cultivars) } \\
\hline 3 & 84 & 2.6 \\
\hline 8 & 85 & 2.9 \\
\hline $\operatorname{LSD}_{0.05}$ & 19 & 0.2 \\
\hline
\end{tabular}

${ }^{2} n=72$ for each cultivar except for 'Karpick' $(n=54)$. y Root scores were determined according to the criteria shown in Table 1. 
water. Foliage was wetted with tap water once hourly for the first 2 days after planting. Plants were arranged randomly in a glasshouse with natural photoperiods, a maximum PAR of $1100 \mu \mathrm{mol} \cdot \mathrm{m}^{-2} \cdot \mathrm{s}^{-1}$, and air at 22 to $44 \mathrm{C}$. Plants were irrigated with tap water once daily for the first week and then three times weekly. Two stems per plant were allowed to develop. Leaf was not completely desiccated. The percentage of the total surface area that was functional on the original two leaves on each cutting was estimated visually on 12 July. Estimates of the percent functional area of trisects of each leaf were made to the nearest $5 \%$ and combined for each cutting. Date of shoot initiation was recorded, and the stem lengths of new shoots were determined on 29 Aug. Destructive harvesting was done on 30 Aug. Dry masses of roots, new shoots, and remaining tissues from the original cuttings were determined after samples were held at $65 \mathrm{C}$ for 3 days. Analysis of variance and correlation procedures were performed (SAS Institute, Cary, N.C.). Pearson's chi-square procedure (Johnson and Bhattacharyya, 1985) was used to determine least significant difference (LSD) values for data expressed as percentages. Fisher's LSD was determined for other dependent variables by using the statistical analysis system (SAS Institute).

\section{Results}

The percentage of cuttings that rooted varied from 22 for 'Karpick' to 100 for 'Schlesinger' (Table 2). Mean root score was lowest for 'Scarlet Sentinel' and 'Karpick' and highest for 'Schlesinger', which did not differ from 'Franksred' (Table 2). Using $8 \mathrm{~g}$ IBA $/ \mathrm{kg}$ caused higher root scores than $3 \mathrm{~g}$ IBA/kg in both years (Table 2). Shoot initiation on rooted cuttings ranged from $3 \%$ for 'Northwood' to $100 \%$ for 'Franksred' (Table 3). 'Franksred' cuttings produced the longest stems on new shoots, and mean stem length for 'Karpick', 'Northwood', and 'Scarlet Sentinel' was $<1 \mathrm{~cm}$ (Table 3 ). The percentage of the leaf surface area that was functional differed among cultivars. 'Autumn Flame', 'Franksred', and 'Schlesinger' had $>90 \%$ funcsurface area was considered functional if it

tional area, and 'Indian Summer', 'Karpick', and 'Scarlet Sentinel' had $<50 \%$ functional area (Table 3). Dry mass of shoots was highest for 'Franksred', and 'Franksred', 'Jeffersred', and 'Schlesinger' had the highest root dry mass (Table 3). Functional surface area of leaves on cuttings was correlated positively with root score for all cultivars except 'Autumn Flame' and 'Karpick' (Table 4). Functional area was correlated with final root dry matter in all cultivars except 'Franksred' and with final shoot dry matter in 'Franksred', 'Indian Summer', 'Karpick', and 'October Glory' (Table 4).

\section{Discussion}

These results show that successfully using single-node cuttings to propagate red maple varies greatly among cultivars and demonstrate that shoot development does not reliably follow root formation in certain genotypes. Cultivars vary in susceptibility to leaf desiccation injury during propagation, and results of correlation tests indicate that preventing leaf injury would increase the growth of propagules, particularly of the root system.

These findings are consistent with those of other researchers who have studied the propagation of one red maple cultivar using singlenode cuttings. Orton (1978) found $98 \%$ rooting of 'October Glory' within 5 weeks. Rooting of single-node cuttings of 'Franksred' was similar to that of triple-node cuttings (Smalley and Dirr, 1987a). Those two cultivars, 'Autumn Flame', 'Jeffersred', and 'Schlesinger' showed $>90 \%$ rooting in our study (Table 2). 'Karpick' and 'Scarlet Sentinel', however, had $<50 \%$ rooting and mean root scores $<1$ (Table 2). These results are strong evidence for genotypic differences in propagation of red maple from single-node cuttings. Additional research is needed to determine whether these differences are specific to single-node cuttings. Rooting of some cultivars might improve if cuttings with two to four nodes were used (Dirr and Heuser, 1987). The difference in mean root score over the 2 years may have been because mean air temperature in the greenhouse during the first 10 days after cuttings were taken was $\approx 10 \mathrm{C}$ higher in 1991 than

Table 3. Shoot initiation, stem length, functional area of leaves on cuttings, and dry mass of plants grown from single-node cuttings of 10 cultivars of red maple and Freeman maple. Stem length and dry masses were determined 10 weeks after rooted cuttings were potted. Functional area of the original two leaves on rooted cuttings was estimated visually 22 days after cuttings were potted.

\begin{tabular}{|c|c|c|c|c|c|}
\hline \multirow[b]{2}{*}{ Cultivar } & \multirow{2}{*}{$\begin{array}{c}\text { Shoot } \\
\text { initiation }(\%)\end{array}$} & \multirow{2}{*}{$\begin{array}{c}\text { Stem } \\
\text { length }(\mathrm{cm})\end{array}$} & \multirow{2}{*}{$\begin{array}{c}\text { Functional area of } \\
\text { leaves on cuttings }(\%)\end{array}$} & \multicolumn{2}{|c|}{ Dry mass $(\mathrm{g})$} \\
\hline & & & & Shoot & Root \\
\hline \multicolumn{6}{|l|}{ Red maple } \\
\hline Autumn Flame & 67 & 8.5 & 94 & 0.53 & 0.78 \\
\hline Franksred & 100 & 22.6 & 97 & 1.30 & 1.38 \\
\hline Karpick & 33 & 0.2 & 19 & 0.03 & 0.04 \\
\hline Northwood & 3 & 0.0 & 53 & 0.00 & 0.31 \\
\hline October Glory & 89 & 11.0 & 80 & 0.75 & 0.86 \\
\hline Schlesinger & 97 & 17.1 & 97 & 0.97 & 1.23 \\
\hline \multicolumn{6}{|l|}{ Freeman maple } \\
\hline Armstrong & 48 & 2.8 & 64 & 0.20 & 0.56 \\
\hline Indian Summer & 93 & 6.1 & 40 & 0.44 & 0.43 \\
\hline Jeffersred & 45 & 3.3 & 78 & 0.25 & 1.10 \\
\hline Scarlet Sentinel & 20 & 0.1 & 25 & 0.02 & 0.12 \\
\hline $\mathrm{LSD}_{0.05}$ & 42 & 2.9 & 14 & 0.19 & 0.22 \\
\hline
\end{tabular}

Table 4. Correlation of functional surface area of the original two leaves on cuttings with root score, root dry mass, and new shoot dry mass of plants grown from single-node cuttings of red maple.

\begin{tabular}{llll}
\hline \hline & \multicolumn{2}{c}{$\begin{array}{l}\text { Pearson correlation coefficients } \\
\text { between functional leaf area and }\end{array}$} \\
\cline { 2 - 4 } Cultivar & $\begin{array}{l}\text { Root } \\
\text { score }\end{array}$ & $\begin{array}{c}\text { Root } \\
\text { dry mass }\end{array}$ & $\begin{array}{c}\text { Shoot } \\
\text { dry mass }\end{array}$ \\
\hline Red maple & & & \\
Autumn Flame & 0.17 & $0.38^{*}$ & 0.11 \\
Franksred & $0.42^{*}$ & 0.31 & $0.34^{*}$ \\
Karpick & 0.01 & $0.81^{* *}$ & $0.79^{* *}$ \\
Northwood & $0.37^{*}$ & $0.82^{* *}$ & -0.22 \\
October Glory & $0.45^{* *}$ & $0.85^{* *}$ & $0.41^{*}$ \\
Schlesinger & $0.38^{*}$ & $0.52^{* *}$ & 0.29 \\
Freeman maple & & & \\
Armstrong & $0.64^{* *}$ & $0.81^{* *}$ & 0.12 \\
Indian Summer & $0.67^{* *}$ & $0.69^{* *}$ & $0.65^{* *}$ \\
Jeffersred & $0.60^{* *}$ & $0.66^{* *}$ & -0.17 \\
Scarlet Sentinel & $0.70^{* *}$ & $0.85^{* *}$ & -0.31 \\
\hline
\end{tabular}

*** Significant at $P=0.05$ or 0.01 , respectively.

in 1990. The higher IBA concentration improved mean root score in both years, but the difference between IBA levels was more pronounced in 1990. Future studies might address whether the optimal IBA concentration for rooting red maple varies with temperature.

Fewer than $50 \%$ of rooted 'Armstrong', 'Jeffersred', 'Karpick', 'Northwood', and 'Scarlet Sentinel' cuttings initiated shoots (Table 3). This phenomenon has not been reported previously and could be a serious problem commercially, especially for 'Northwood' and 'Scarlet Sentinel', which had $3 \%$ and $20 \%$ shoot initiation, respectively (Table 3). In subsequent experiments (data not presented), we observed that removal of bud scales of rooted cuttings induced shoot initiation in 'Jeffersred', suggesting that endogenous growth-inhibitory substances in the bud scales may have been responsible for bud dormancy. Additional research should be designed to determine the physiological basis for the poor shoot initiation of some cultivars so that methods to overcome the problem can be developed.

Differences among cultivars in the amount of leaf desiccation that occurred after cuttings were removed from the propagation bench (Table 3) and the positive correlation of the functional leaf surface with the final root or shoot dry mass of propagules for all cultivars (Table 4) illustrate the importance of minimizing foliar damage after cuttings are rooted. Despite reducing the frequency and duration of mist episodes before cuttings were removed from the propagation bench, functional leaf surface was $<50 \%$ for three of the cultivars $\approx 3$ weeks after cuttings were planted and moved from the mist bench (Table 3). Positive correlation of root scores with functional leaf surface for eight of the 10 cultivars (Table 4) indicates that propagators should allow cuttings to root extensively before removing them from the propagation bench. The percentage of the leaf surface that was functional on 'Indian Summer' and 'Northwood' was less than that on 'Jeffersred' and 'October Glory' (Table 4), even though the root scores of these four cultivars were similar (Table 2 ). This lack 
of agreement suggests that the leaves of the various cultivars varied in resistance to desiccation after removal from the propagation bench. The humidification regime should be managed to account for differences in rooting and the susceptibility to leaf injury among cultivars.

\section{Literature Cited}

Bachtell, K.R. 1989. A fortunate blend: Freeman maple, a hybrid of red and silver maples, shows promise for tough urban sites. Amer. Nursery$\operatorname{man} 169(8): 40-55$

Dirr, M.A. 1990. Manual of woody landscape plants. Their identification, ornamental characteristics, culture, propagation and uses. 4th ed. Stipes, Champaign, Ill.

Dirr, M.A. and C.W. Heuser, Jr. 1987. The reference manual of woody plant propagation. Varsity Press, Athens, Ga.

English, J.A. 1981. Rooting Acer rubrum cultivars using single node cuttings. Proc. Intl. Plant Prop. Soc. 31:147-150.

Fare, D.C., C.H. Gilliam, and H.G. Ponder. 1990. Acer rubrum cultivars for the south. J. Arboricult. 16:25-29.

Johnson, R. and G. Bhattacharyya. 1985. Statistics principles and methods. Wiley, New York.

Moller, G.M. 1985. How one Oregon grower produces trees from softwood cuttings. Amer. Nurseryman 162(4):68-69.
Orton, E.R., Jr. 1978. Single-node cuttings: A simple method for the rapid propagation of plants of selected clones of Acer rubrum L. The Plant Propagator 24(3):12-15.

Smalley, T.J. and M.A. Dirr. 1987a. Effect of cutting size on rooting and subsequent growth of Acer rubrum 'Red Sunset' cuttings. J. Environ. Hort. 5:122-124.

Smalley, T.J. and M.A. Dirr. 1987b. Effect of extended photoperiod on budbreak, overwinter survival, and carbohydrate levels of Acer rubrum 'October Glory' rooted cuttings. J. Amer. Soc. Hort. Sci. 112:459-463.

Townsend, A.M. 1977. Characteristics of red maple progenies from different geographic areas. J. Amer. Soc. Hort. Sci. 102:461-466. 